\title{
The Xanthate Route to Amino Acids
}

\author{
Samir Z. Zard*a
}

\begin{abstract}
The degenerative xanthate addition transfer to alkenes allows the synthesis of a broad range of protected, and in some cases enantiopure, $\alpha, \beta$, and $\gamma$-amino acids, including proline and pipecolic derivatives, as well as fluorinated congeners and $\beta$-lactams. The radical addition furnishes naturally latent mercapto- $\alpha$-amino acids that are ideally equipped for native chemical ligation. Most of the amino acid structures accessible rapidly by this chemistry would otherwise require tedious multi-step syntheses.
\end{abstract}

Keywords: Amino acids · $\beta$-Lactams · Native chemical ligation $\cdot$ Radical addition $\cdot$ Xanthates

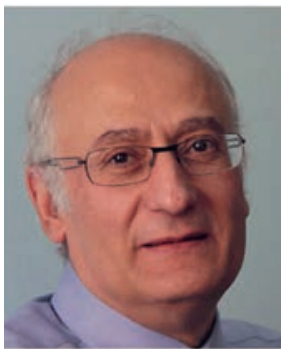

Samir Z. Zard was born in 1955 in Ife, Nigeria. His training as a chemist started at the American University of Beirut, then at Imperial College, London, and finally at the Université Paris-Sud, Orsay, France, where he received his doctorate under the supervision of Professor Sir Derek Barton in 1983. His main research concerns the study and development of new reactions and processes, with a special interest in radicals, organosulfur derivatives, alkynes, and nitro compounds. In addition to a number of academic awards, he received in 2007 the Croix de Chevalier de la Légion d'Honneur.

\section{Introduction}

$\alpha$-Amino acids constitute fundamental building blocks for peptides. In addition to the twenty or so proteinogenic $\alpha$-amino acids, numerous unnatural $\alpha$-amino acids have been prepared and used in the fashioning of modified peptides, peptidomimetics, drugs, natural products, ligands for transition metals, and so on.$^{[1]}$ The homologous $\beta$ - and $\gamma$-amino acids are also of considerable value and have in consequence attracted much attention. ${ }^{[2]}$ Both types are found in natural products and drug substances. They are precursors of $\beta$ - and $\gamma$-lactams, and $\beta$-amino acid derived peptidomimetics are metabolically stable and therefore particularly useful in medicinal chemistry. The exceptional importance of this family of compounds is reflected by the extensive efforts, spanning many decades, devoted to the design and development of broadly applicable methods for their synthesis. ${ }^{[3]}$ In this brief overview, the potential of the degenerative radical addition-transfer of xanthates for the synthesis of $\alpha-, \beta$-, and $\gamma$-amino acids will be discussed.

\section{The Degenerative Radical Addition-transfer of Xanthates}

The xanthate transfer is based on the unique ability of xanthates and related derivatives to store reactive radicals in a dormant form, thereby enhancing significantly their lifetime in a concentrated medium, while simultaneously regulating their absolute and relative concentrations. ${ }^{[4]}$ The mechanism of the xanthate addition, outlined in simplified form in Scheme 1, exhibits several features: (a) the reaction of $\mathrm{R} \bullet$ with xanthate $\mathbf{3}$, its precursor, is reversible and degenerate. It gives rise to adduct $\mathbf{4}$, a radical stabilised by three heteroatoms that is too bulky to react fast with other radicals and is unable to disproportionate (no $\beta$-hydrogens). It can therefore only fragment back to $\mathrm{R} \bullet$. The continuous regen- eration of starting radical $\mathrm{R} \cdot$ increases considerably its effective lifetime, allowing it to react even with unactivated alkene $\mathbf{1}$ to furnish adduct 2 . This new radical is in turn captured reversibly by the xanthate to give intermediate $\mathbf{5}$ (likewise a dormant species). (b) Because the equilibrium generally favours adducts $\mathbf{4}$ and $\mathbf{5}$, active radicals $\mathrm{R} \cdot$ and $\mathbf{2}$ are reversibly stored in an inactive dormant state most of the time. In consequence, their absolute steady state concentration remains extremely low, and undesired radical-radical interactions become insignificant. (c) Since radicals $\mathrm{R} \bullet$ and $\mathbf{2}$ are in equilibrium via intermediate $\mathbf{5}$, it is possible to modulate their relative concentration by a suitable choice of partners so as to favour the production of adduct 6 and avoid the formation of unwanted oligomers 7.

The actual mechanism is subtler and more intricate than the manifold displayed in Scheme 1. The interested reader is directed to the articles in ref. [5] for a more detailed mechanistic discussion. From a preparative standpoint, this process offers numerous advantages, namely: non-toxic and very inexpensive reagents (bulk price 2-5 USD per kg); safe and easily scalable procedures; ability to operate in highly concentrated media, and sometimes even without a solvent; and, not least, a good compatibility with most functional groups, especially polar functions that often require protection with other chemistries. Well over 2000 addi-

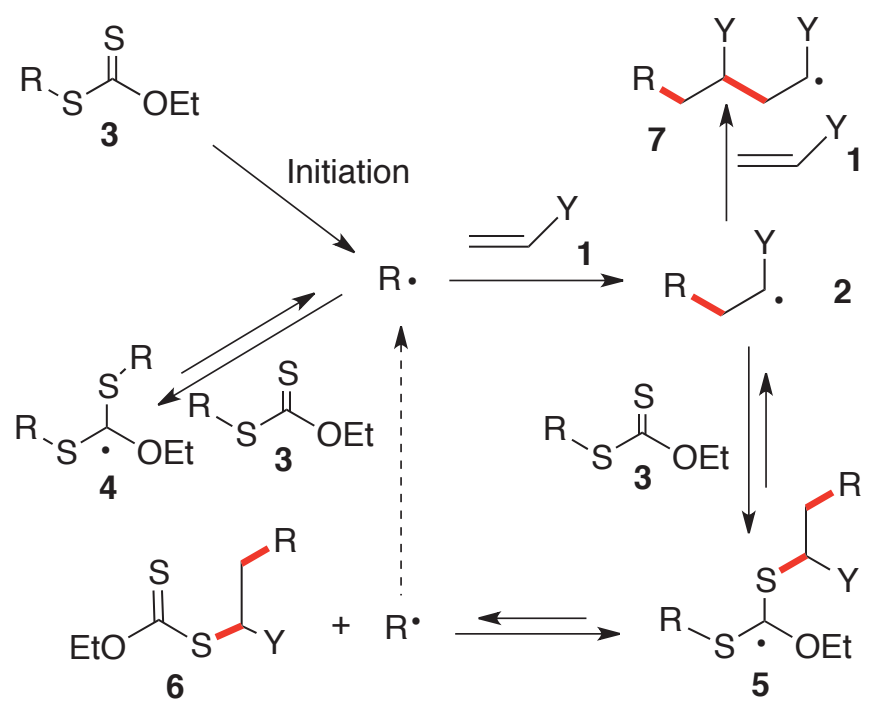

Scheme 1. Simplified mechanism for the xanthate addition to an alkene. 
tions, involving several hundred different xanthates, have been described so far. For the synthesis of amino acids, the masked amino acid moiety can be attached to either the xanthate or the alkene partner (or indeed both). These two approaches will be discussed in the next sections.

\section{Xanthates Bearing the Amino Acid Motif}

The approach where the xanthate group is attached to the amino acid moiety will first be illustrated by two cyclisation reactions involving $\beta$-lactam chloride $\mathbf{8}$ and the corresponding xanthate $\mathbf{1 3}$ (Scheme 2; the amino acid portion is coloured in blue). The two experiments will serve to underscore the difference in the lifetime of the intermediate radicals when applying the classical stannane chemistry as compared to the tin-free xanthate transfer. Thus, treatment of chloride $\mathbf{8}$ with tributyltin hydride at a concentration of $0.02 \mathrm{M}$ furnishes the desired bicyclic compound $\mathbf{1 1}$ as the minor product. ${ }^{[6]}$ At this concentration, intermediate radical 9 is mostly prematurely reduced to give uncyclized product $\mathbf{1 0}$. By lowering the concentration to $0.003 \mathrm{M}$, the formation of uncyclized product $\mathbf{1 0}$ is strongly curtailed and the yield of bicyclic $\beta$-lactam 11 increases to $50 \%$. Unfortunately, the very high dilution encourages the formation of phenylated compound 12, arising by attack of the cyclised radical on the benzene solvent.

In dramatic contrast, heating a solution of xanthate $\mathbf{1 3}$ in refluxing cyclohexane in the presence of a small amount of dilauroyl peroxide (DLP, also sold under lauroyl peroxide, Laurox ${ }^{\circledR}$ or Luperox LP $^{\circledR}$ ) furnishes cleanly the cyclised product 14 in good yield, even though the concentration is nearly 100-fold greater than that of the stannane reaction. ${ }^{[7]}$ The same intermediate radical $\mathbf{9}$ is implicated, but its reaction with its xanthate precursor $\mathbf{1 3}$ is reversible and degenerate. It is therefore not consumed in useless side reactions because its lifetime is increased sufficiently to permit an essentially complete cyclisation, even under much more concentrated conditions.

The addition of a protected amino acid motif bearing a xanthate group was applied early on by Speckamp and Hiemstra for the synthesis of both cyclic and open chain amino acids. ${ }^{[8]}$ The examples of cyclic amino acids are pictured in Scheme 3. ${ }^{[8]}$ ] The ring-closure of xanthate $\mathbf{1 5}$ was accomplished under two different conditions. Initiation with di-t-butyl peroxide at high temperature (conditions A) furnished the 6-endo and 5-exo products $\mathbf{1 6}$ and $\mathbf{1 7}$, respectively, in $64 \%$ combined yield and in a 1:5 ratio. Initiation using visible light in combination with a small amount of $S$-benzoyl xanthate gave the same mixture of compounds $\mathbf{1 6}$ and $\mathbf{1 7}$ in similar ratio, but in a better yield and a higher selectivity as far as the cis/trans ratio is concerned. The yellow-coloured $S$-benzoyl xanthate absorbs in the visible region of the spectrum; it initiates the radical chain without being consumed in the process. ${ }^{[9]}$ The cyclisation of xanthates $\mathbf{1 8}$ and $\mathbf{2 0}$ proceeds by a 6-exo mode to give the corresponding pipecolic derivatives 19 and 21 in good yield as mixtures of diastereoisomers.

The intermolecular variant is illustrated by the addition of xanthate $\mathbf{2 2}$ to a variety of alkenes to give protected amino acids 23a-g (Scheme 4). ${ }^{[8 b]}$ Compound $\mathbf{2 3 f}$ arises from the addition to 1,5-cyclooctadiene and thus involves an extra cyclisation step. In the case of the last example, the xanthate group was reductively removed to give the sulfur-free product $\mathbf{2 4}$. The convergence of this approach makes the construction of a library of amino acids, by simply varying the alkene partner, relatively easy.

Placing two carbamate groups on the nitrogen as in xanthate 25 results in a somewhat more reactive radical and additions can be performed under milder conditions. This is illustrated by addition to tris(t-butoxy)vinylsilane to give adduct 26 (Scheme 5). [10] A second example is addition-fragmentation to alkene 27, which furnishes protected amino acid $\mathbf{2 8}$ possessing a glucose-derived carbohydrate side-chain. ${ }^{[11]}$ The fluoropyridoxyl motif has proved extremely useful in converting allylic alcohols into radical allylat-

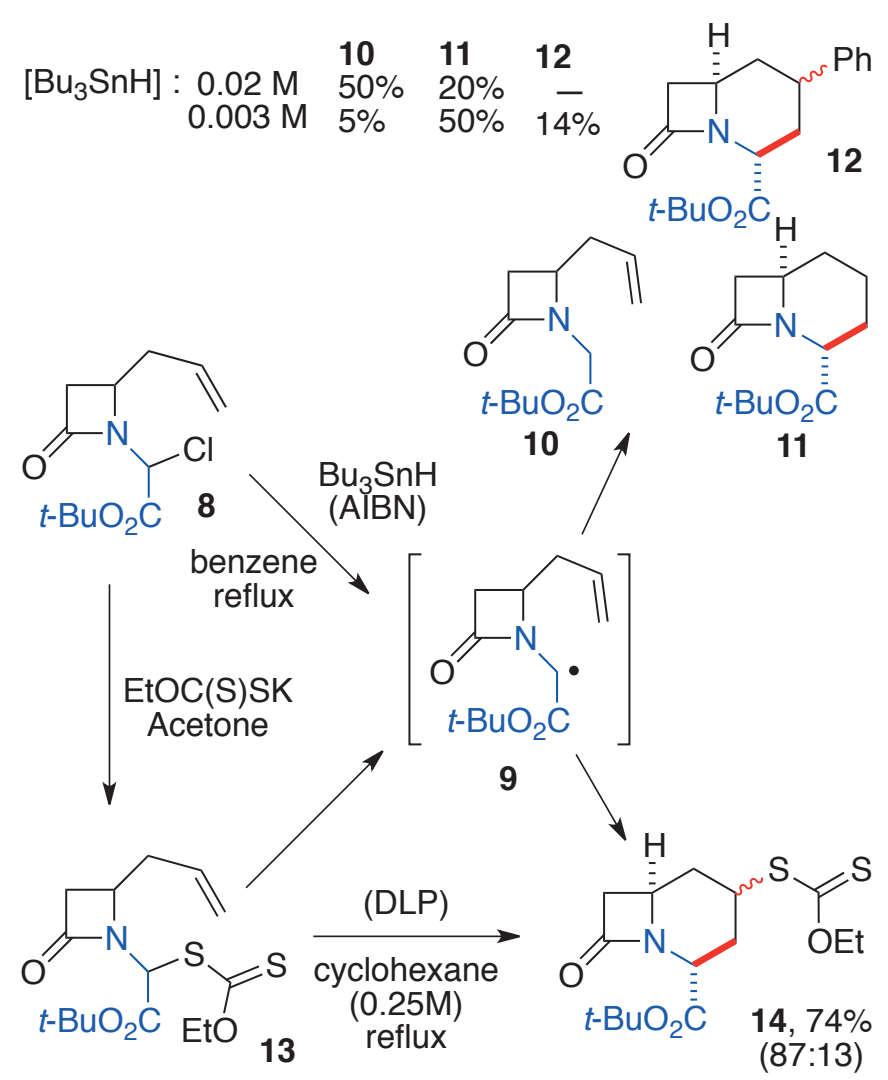

Scheme 2. Two methods for ring formation on a $\beta$-lactam.

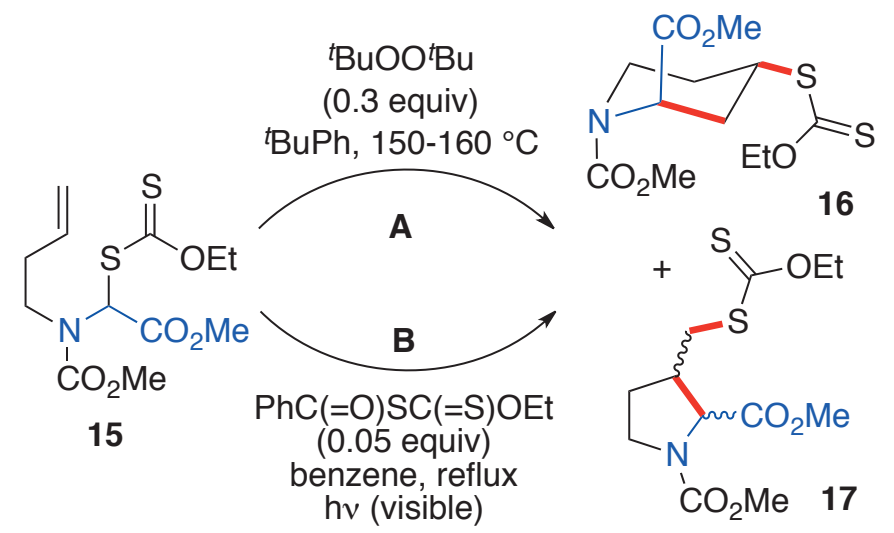

A: $64 \%(16: 17=16: 84) ; 17($ cis/trans $=36: 64)$

B: $92 \%(16: 17=20: 80) ; 17($ cis/trans $=18: 82)$<smiles>CC/C=C\CCCN(C(C)=O)C([Si]OCC)C(C)=[Si]OCC</smiles>

18

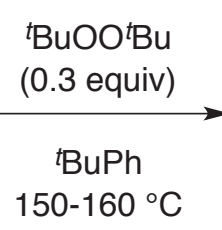<smiles>CCO[SiH2][SiH2]C([SiH2]OCC)C1CCCN(C(C)=O)[C@H]1C(OC)OC</smiles>

$19,73 \%$

(4 isomers)

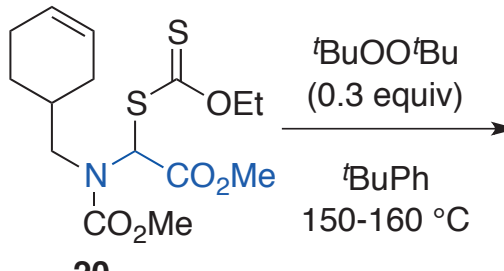

20

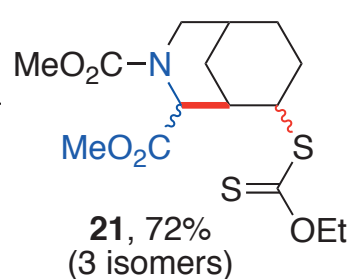

Scheme 3. Formation of protected cyclic amino acids. 


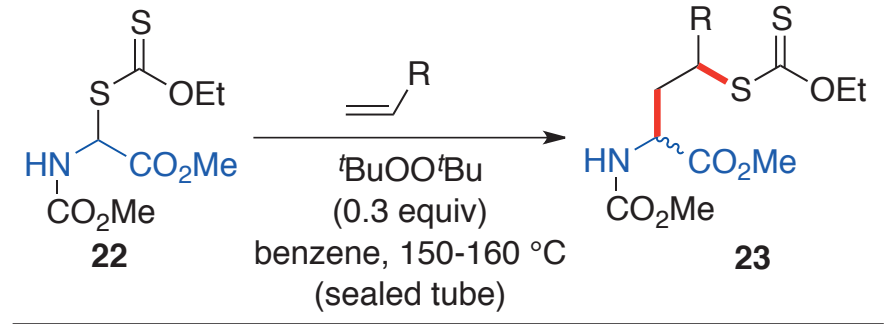

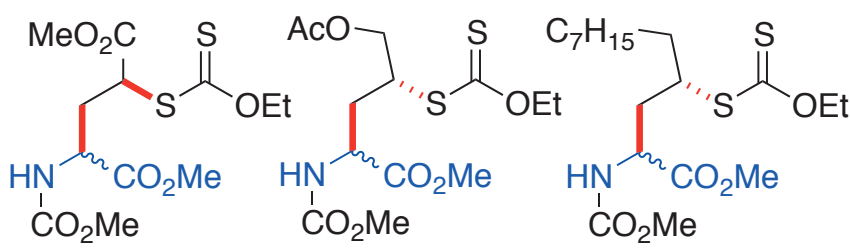

23a, $55 \%$

23b, $41 \%$

23c, $75 \%$<smiles>CCOC(=S)SC1C2CC3CC1C(C2NC(C)=O)C3C(C)=O</smiles>

23d, $69 \%$ (endo/exo $=81: 19)$<smiles>CCOC(=O)S[C@H]1C(=O)N(C)C(=O)[C@H]1C(NC(C)=O)OC</smiles>

23e, $49 \%$<smiles>CCOC(=S)SC1CCC2C(C(NC(C)=O)OCC)CCCC12</smiles>

23f, $75 \%$<smiles>[X]C1CCCC1C(NC(C)=O)C(O)OC</smiles>

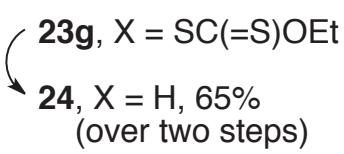

(over two steps)

Scheme 4. Formation of protected amino acids.

ing agents. ${ }^{[12]}$ The synthetic implications of these highly versatile transformations are indeed far reaching. The last sequence in Scheme 5, starting with allyl aniline substrate $\mathbf{2 9}$ and xanthate 30, highlights the possibility of following the radical addition by a ring-closure onto an aromatic ring. Thus, further exposure of adduct $\mathbf{3 1}$ to stoichiometric amounts of peroxide gives rise to the formation of indoline 32. ${ }^{[13]}$ This compound can be converted into indole 33 by a brief treatment with cold concentrated sulfuric acid (the yield in parenthesis is based on recovered starting material). The success of this last step hinges on the presence of the suitably positioned electron releasing methoxy substituent, which facilitates the departure of the sulfonyl group and formation of indole 33.

Skrydstrup and co-workers studied an extension to dipeptide xanthates 34.[14] They examined additions to acrylonitrile and allyl trimethylsilane, and reduced the corresponding adducts in situ using a combination of stoichiometric DLP in isopropanol (Scheme 6). ${ }^{[15]}$ Compounds $\mathbf{3 5 a}-\mathbf{f}$ were thus obtained in modest yields over the two steps. Allylation with allyl ethyl sulfone ${ }^{[16]}$ was also explored as illustrated by the formation of products $\mathbf{3 6 a}-\mathbf{d}$.

A similar strategy can be used to access protected $\beta^{3}$-amino acid. According to nomenclature proposed by Seebach, ${ }^{[17]} \beta^{3}$ - indicates that the substituent in the $\beta$-amino acid is on the carbon bearing the amino group. Such $\beta$-amino acids in protected form, 38, can be obtained by addition of xanthate 37 to various alkenes, ${ }^{[18]}$ then reducing off the xanthate group in the corresponding adducts using hypophosphorous acid salts, according to the method introduced by Barton (Scheme 7).[19] The success of these additions hinges on the ability of the phthalimide (and imides in general) to stabilise the adjacent radical by providing it with a certain allylic character. ${ }^{[20]}$ Examples 38a-k are representative of structures accessible by this approach. Noteworthy are $\beta$-amino acids $\mathbf{3 8 j}$, pos-

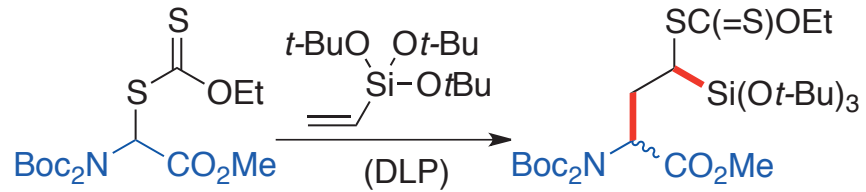

25 EtOAc, reflux

26, $54 \%$

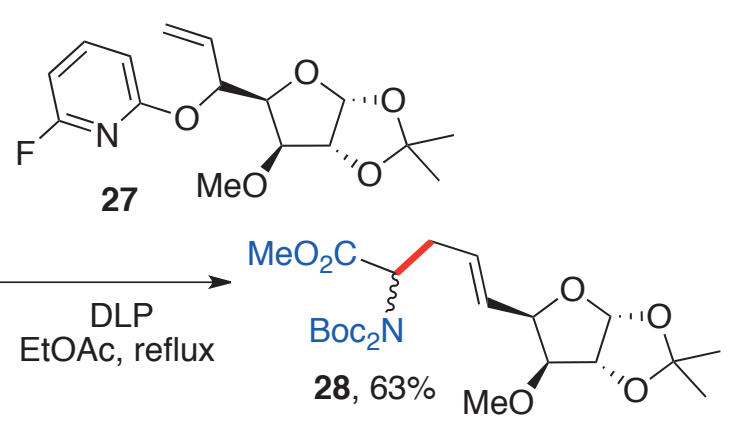<smiles>C=CCN(c1ccc(OC)cc1)S(=O)(=O)c1ccccc1</smiles><smiles>CCOC(=O)NC(CC(CN(c1ccc(OC)cc1)S(=O)(=O)OC)(SC(=S)OCC)c1ccccc1)C(C)=O</smiles>

$32,60 \%$

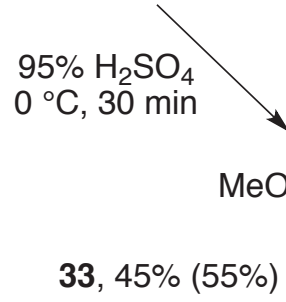

$31,70 \%$

33, $45 \%(55 \%)$<smiles>CC(=O)NC(Cc1c[nH]c2ccc(C)cc12)C(C)=O</smiles>

Scheme 5. Variations on the synthesis of protected amino acids.

sessing an unusual fluorinated side-chain, and $\mathbf{3 8 g}$ and $\mathbf{3 8 h}$, where cyclization of the unmasked amine with the ketone would lead to medicinally relevant bicyclic $\beta$-amino acid derivatives. Another interesting compound in Scheme 7 is adduct 38d. It corresponds to methyl $\beta$-lysinate, where the two amino groups are protected as phthalimides. $\beta$-Lysine (or isolysine) is biosynthetically derived from lysine itself by the action of lysine 2,3-aminomutase, a SAM dependent enzyme. ${ }^{[21]}$ Along with $\beta$-alanine and $\beta$-leucine, it is one of the earlier $\beta$-amino acids found in nature. It is present in tears, where it acts as an antibiotic by causing lysis of numerous Gram-positive bacteria, and in blood platelets during coagulation. It is also a subunit of several antibiotics isolated chiefly from Steptomyces strains in the middle of last century, such as viomycin, streptolin and streptothricin. ${ }^{[22]}$

Shifting the xanthate to the carbon bearing the ester group provides a route to protected $\beta^{2}$-amino acids. Two exemplars of this alternative are presented at the top of Scheme 8. Thus, addition of xanthate $39(\mathrm{R}=\mathrm{Me})$ to allyl pinacolato boronate gives adduct 40 in high yield. ${ }^{[23]}$ Obviously, many other alkenes can be employed as the radical traps. Moreover, the free acid itself can be used if so desired, as demonstrated by the conversion of xanthate $39(\mathrm{R}=\mathrm{H})$ into protected $\beta$-amino acid $\mathbf{4 1}$. The ability to create carbon-carbon bonds starting with free carboxylic acids, even though rarely applied, is a hallmark of radical reactions in general. 


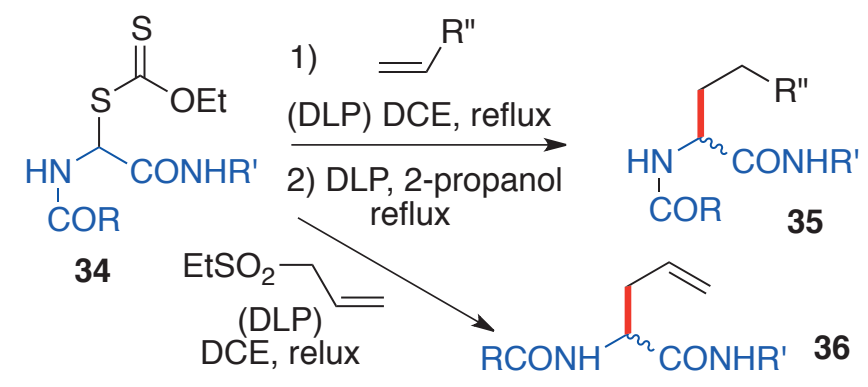<smiles>COC(=O)C(Cc1ccccc1)NC(=O)C(CCC#N)NC(=O)c1ccccc1</smiles>

35a, $50 \%$<smiles>COC(=O)C(NC(=O)C(CCC#N)NC(=O)c1ccccc1)C(C)C</smiles>

35c, $43 \%$<smiles>CC(=O)OC(CCCC#N)NC(=O)C(CC(C)C)N[C@@H](CC(C)C)C(C)=O</smiles>

35e, $23 \%$<smiles>C=CC[C@H](NC(=O)c1ccccc1)C(=O)NC(Cc1ccccc1)Cc1ccccc1</smiles>

36a, $57 \%$<smiles>C=CCC(NC(=O)c1ccccc1)C(=O)N1CCCC1C(C)=O</smiles>

36 c, $30 \%$<smiles>CCCCCCC(Cc1ccccc1)C(=O)NC(CC[SiH3])C(=O)OCc1ccccc1</smiles>

35b, $37 \%$<smiles>CC(=O)OC1CCCN1C(=O)C(CCC#N)NC(=O)c1ccccc1</smiles>

35 d, $20 \%$<smiles>CC(C)C[C@H](NC(=O)c1ccccc1)C(=O)N[C@@H](CCCN)C(=O)NC(Cc1ccccc1)C(=O)OCc1ccccc1</smiles><smiles>C=CCC(NC(=O)c1ccccc1)C(=O)NC(C(C)=O)C(C)C</smiles>

36b, $33 \%$
Scheme 6. Synthesis of dipeptides.

$\beta$-Amino acids are of major importance in the total synthesis of natural products, a number of which embody such motifs (e.g. $\beta$-lactams, toxoids, etc.), in the synthesis of medicinal substances, and for the assembly of metabolically stable peptidomimetics. ${ }^{[2]}$ This approach to amino acids is quite general. Furthermore, the distance between the amino and acid groups can be modified at will. $\gamma$-Amino acids, for instance, represent another family of significant building blocks since they may be viewed as analogues of $\gamma$-aminobutyric acid (GABA). [2f] The five examples, 43a-e, displayed in the lower part of Scheme 8 were easily obtained by addition of xanthate $\mathbf{4 2}$ to various alkenes followed by reductive removal of the xanthate group in the initial adducts. ${ }^{[24]}$

\section{Alkenes Bearing an Amino Acid Motif}

An alternative and equally powerful strategy is to place the amino acid motif on the alkene and introduce the diversity through the xanthate partner. One such example is outlined in Scheme 9. It involves the addition of $S$-acyl xanthate $\mathbf{4 4}$ to protected allylglycine 45 to give the corresponding addition product 47. ${ }^{[25]}$ This reaction exhibits a few interesting features. Firstly, intermediate acyl radical 46 does not undergo ring opening of the strained cy-

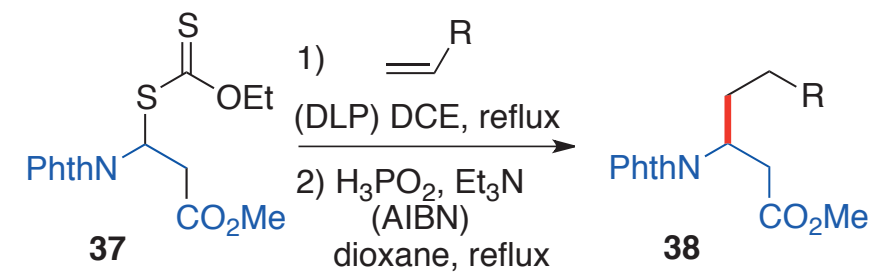

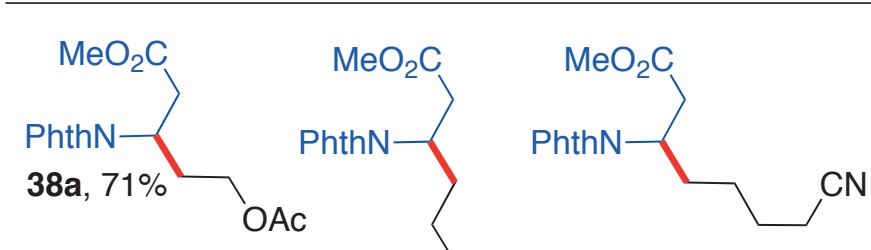<smiles></smiles><smiles></smiles>

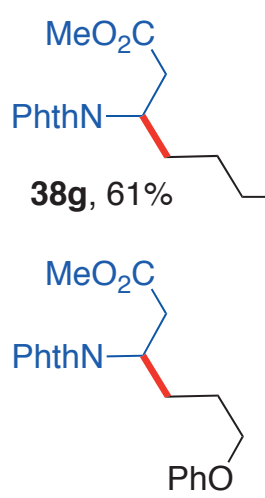

38i, $78 \%$

38j, $57 \%$<smiles>COC(=O)CC(CCCC1CCC2CCCCC21)Nc1ccccc1</smiles><smiles>COC(=O)NC(CCC(CCCOc1ccc(Br)cc1)NPc1ccccc1)CCC(O)(C(F)(F)F)C(F)(F)F</smiles>

38k, $64 \%$

clopropane, in contrast to the analogous cyclopropyalkyl radicals, which rupture extremely rapidly with first order rate constants around $10^{8} \mathrm{~s}^{-1} \cdot{ }^{[26]}$ Nor does it extrude carbon monoxide, unlike typical tertiary acyl radicals. ${ }^{[27]}$ Secondly, the xanthate group in adduct $\mathbf{4 7}$ is $\beta$ - to the ketone and can thus be eliminated by brief treatment with a base such as DBU. When the reaction is conducted at $0{ }^{\circ} \mathrm{C}$, enone $\mathbf{4 8}$ is produced in high yield. In contrast, operating at room temperature results in migration of the alkene via the extended enolate to furnish ultimately enamide 49. The asymmetric hydrogenation of enamides is a well-established route to optically pure amino acids. ${ }^{[28]}$ In the present case, this would lead to derivative 50, which could be converted if so desired into tetrahydropyridine $\mathbf{5 1}$ by selective deprotection of the amino group. Ring expansion of the cyclopropyl group would constitute another path for diversification.

Addition of various xanthates to the optically pure allylglycine 45 would represent a simple approach to non-racemic $\alpha$-amino acids. Protected vinylglycine 52, a compound readily prepared from L-methionine, is another very attractive precursor to a broad range of non-racemic $\alpha$-amino acids. Incidentally, vinyl glycine itself is a natural product isolated from certain mushrooms and reported to be an inhibitor of pyridoxal-linked aspartate aminotransferase. ${ }^{[29]}$ The remarkable diversity of additions to alkene $\mathbf{5 2}$ is illustrated by the numerous examples provided in Scheme 10. ${ }^{[30]}$ A tertiary butyl group $(\mathbf{5 4 c})$ as well as more polar nitrile $(\mathbf{5 4 a}, \mathbf{b})$, ester $(\mathbf{5 4 d})$, and Weinreb amide (54e), are all easily introduced. Examples $\mathbf{5 4 f - i}$ arise by addition of $\alpha$-ketonyl xanthates bearing various substituents and provide access to amino acids that would be exceedingly 


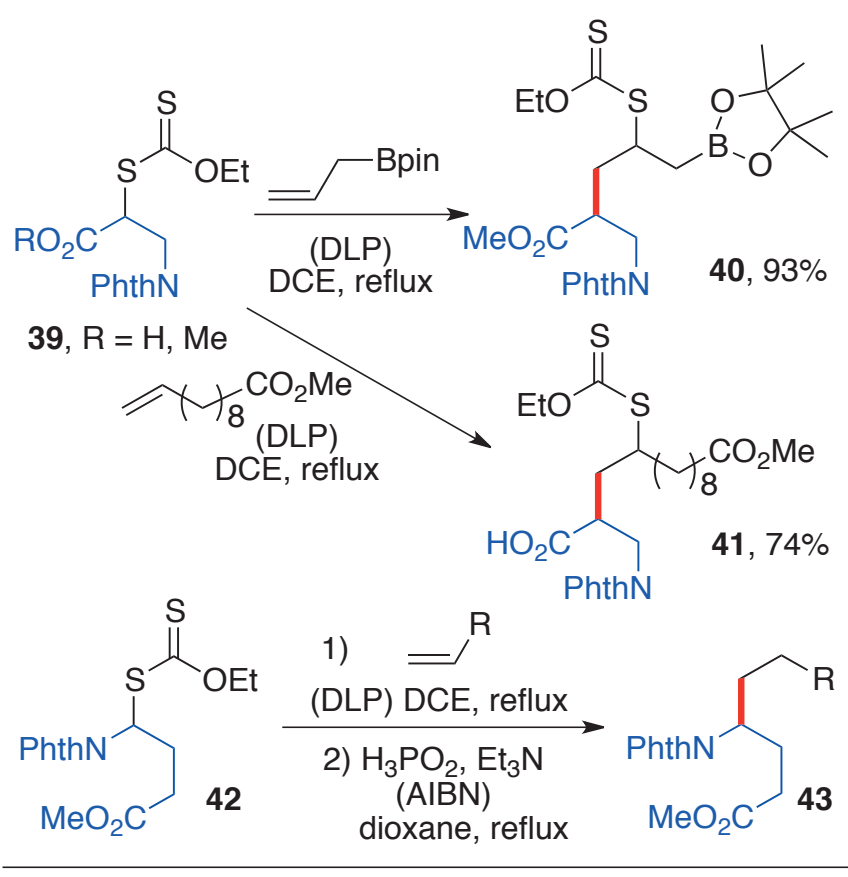

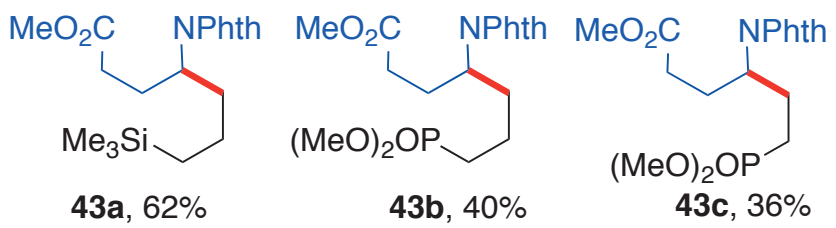<smiles>COC(=O)CCC(CCC1COC(=O)O1)Nc1ccccc1</smiles>

Scheme 8 . Synthesis of protected $\beta$ - and $\gamma$-amino acids.

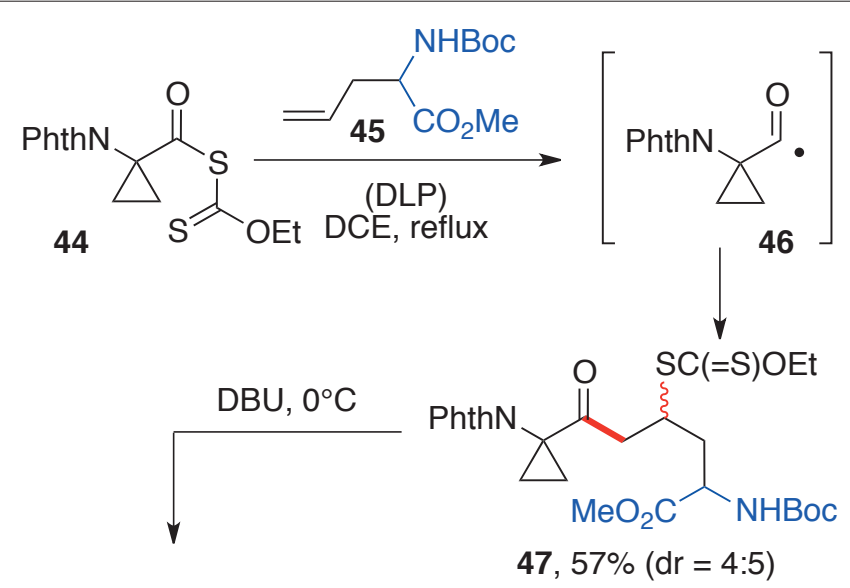

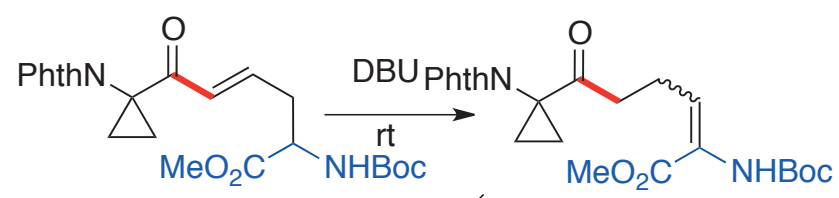

$48,86 \%$

$49,72 \%$

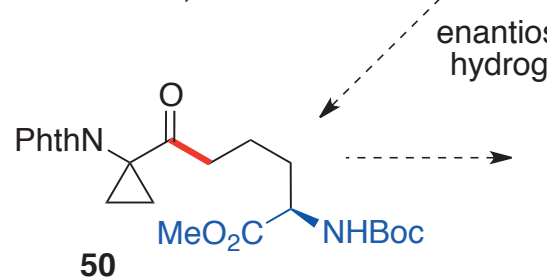

genation<smiles>CC(=O)C1CCCC(C2(Nc3ccccc3)CC2)=N1</smiles>

Scheme 9. Addition of cyclopropylacyl radicals. tedious to obtain by more conventional methods. The last example corresponds to the synthesis of protected ornithine $\mathbf{5 4} \mathbf{j}$. The amino group in this compound was deprotected by catalytic hydrogenation and converted into the corresponding Mosher amide (not shown), which allowed us, by comparison with authentic material, to confirm that no significant racemisation occurred during the radical addition and reductive dexanthylation steps.

Xanthate $\mathbf{5 5}$ is readily obtained from commercially available 1-bromo-3,3,3-trifluoro-2-propanone. ${ }^{[31]}$ Its addition to protected vinylglycine 52 furnishes the expected adduct 56 (Scheme 11). The use of an $O$-neopentyl xanthate instead of the ubiquitous $O$-ethyl xanthate is not strictly necessary but it makes the reaction more reproducible. Trifluoromethyl ketones easily form hydrates, ${ }^{[32]}$ which in this case modifies the stability of the intermediate radical. The bulkier and more hydrophobic $O$-neopentyl xanthate slows down the hydration process. Reductive removal of the xanthate furnishes protected amino acid $\mathbf{5 7}$ which, upon deprotection of the amine by catalytic hydrogenation, gives rise to pipecolic ester $\mathbf{5 8}$ by spontaneous cyclisation of the liberated amine onto the ketone and in situ stereoselective reduction of the resulting cyclic imine. This route is not only the shortest to the rare methyl 2-trifluormethyl-6-pipecolate $\mathbf{5 8}$, it is just one example of a broader strategy for the synthesis of optically pure pipecolates (and indeed piperidines in general) since any of the keto amino

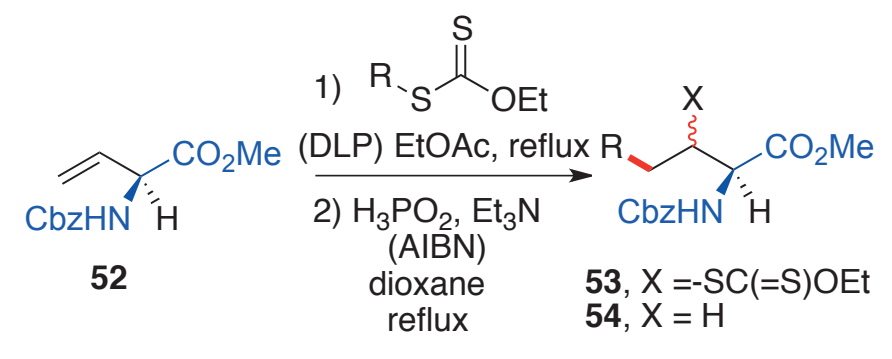<smiles></smiles>

53a, $82 \%$; 54b, $80 \%$<smiles>[X]C(CC(C)(C)C)C(NC(C)=O)C(C)=O</smiles><smiles>[X]C(CC(C)(C)C)C(NC(C)=O)C(C)=O</smiles>

53b, 54\%; 54b, 70\%<smiles>[X]C(CCC(=O)N(C)OC)C(NC(C)=O)C(C)=O</smiles>

53e, $68 \%$; $54 e$, $80 \%$<smiles>[X]C(CCC(C)=O)C(N[O+]([O-])O[Na])C(C)=O</smiles>

53d, $81 \%$; 54d, 73\%<smiles>[X]C(CCC(=O)CCl)C(NC(C)=O)C(C)=O</smiles>

53g, 67\%; 54g, 79\%<smiles>[X]C(CCC(=O)CNc1ccccc1)C(NC(=O)O)C(C)=O</smiles>

53i, 61\%; 54i, 73\%<smiles>[X]C(CCC(=O)C1CC1)C(N[O+]([O-])O)C(C)=O</smiles>

53f, $60 \%$; 54f, $79 \%$<smiles>[X]C(CCC(=O)C(OC)OC)C(NC(C)=O)C(C)=O</smiles>

53h, 73\%; 54h, 80\%<smiles>[X]C(CCNc1ccccc1)C(N[O+]([O-])O)C(C)=O</smiles>

53j, 68\%; 54j, 83\% 
acids $\mathbf{5 4} \mathbf{f}-\mathbf{i}$ could be converted into the corresponding pipecolates by a similar treatment.

The rigid structure of proline has a strong influence on the tertiary and quaternary structures of proteins and on their biological activity. ${ }^{[33]}$ Proline therefore occupies a very special position among the essential amino acids. Two related olefinic partners

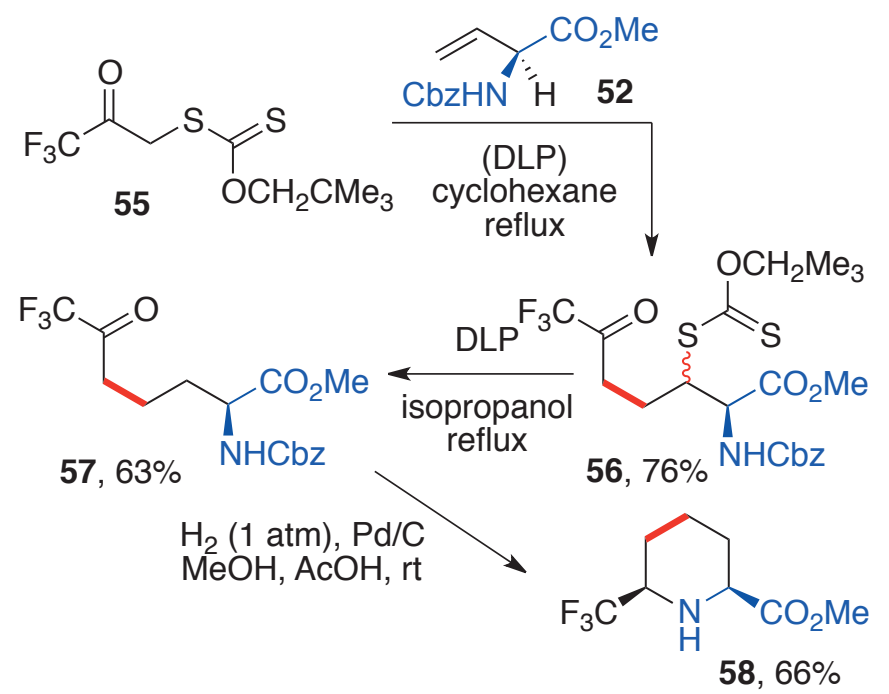

Scheme 11. Synthesis of enantiopure methyl 2-trifluoromethyl-6-pipecolate.

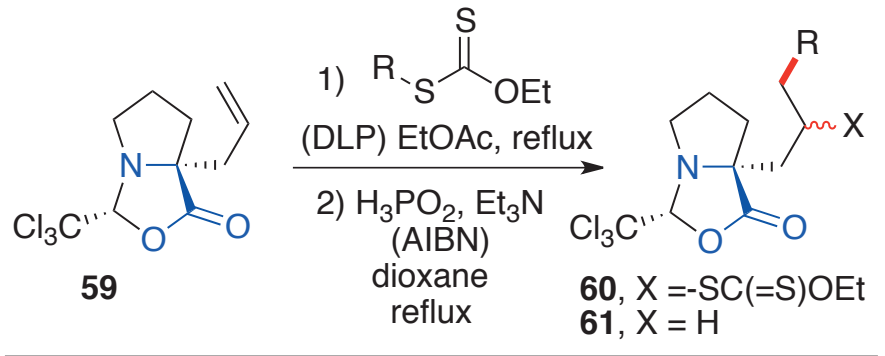<smiles>[X]C(CCC#N)C[C@]12CCCN1[C@@H]([CH]Cl)OC2=O</smiles><smiles>[X]C(CCC(OC)OC)CC12CCCN1[C@@H](C)OC2=O</smiles>

$60 a, 86 \% ; 61 a, 76 \%$

60b, $77 \%$; 61b, $70 \%$<smiles>[X]C(CCC(C)=O)C[C@]12CCCN1[C@H](C(Cl)(Cl)Cl)OC2=O</smiles>

60c, $79 \%$; 61c, $77 \%$<smiles>[X]C(CCC(=O)c1ccc(Br)cc1)C[C@]12CCCN1[C@@H](C(Cl)(Cl)Cl)OC2=O</smiles><smiles>[X]C(C)C[C@]12CCCN1[C@@H]([CH])OC2=O</smiles>

60 e, $80 \%$; 61 e, $73 \%$

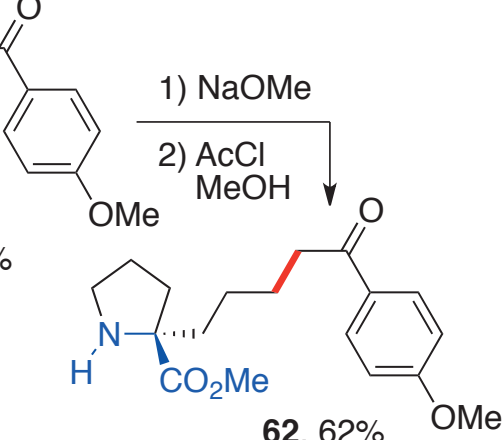

were used for the synthesis of proline derivatives. Oxazolone 59, obtained according to the procedure of Williams, ${ }^{[34]}$ is the first. The desired additions proceeded smoothly, as shown by examples 61a-e compiled in Scheme 12. No racemization can take place in this case and, fortunately, no interference from the trichloromethyl group was observed. Polychlorinated derivatives are known to undergo Kharasch-type chlorine atom transfer, but the process must be significantly slower than the exchange of the xanthate group. The deprotection was tested on product 61 e. Thus, exposure to sodium methoxide opens the cyclic aminal with expulsion of chloroform, and the resulting $\mathrm{N}$-formyl intermediate (not shown) is cleaved by treatment with methanolic $\mathrm{HCl}$ to give methyl prolinate $\mathbf{6 2}$.

The second is the more conveniently protected allyl $\mathrm{N}$-Bocproline 63 that is easily prepared from the first alkene 59. It also reacts readily with an assortment of xanthates and the corresponding adducts $64 \mathbf{a}-\mathbf{g}$ could be cleanly desulfurized into proline derivatives $\mathbf{6 5} \mathbf{a}-\mathbf{g}$ (Scheme 13). It is interesting to note that compound $65 \mathrm{f}$ can be viewed as a protected hybrid of proline and lysine and that cyanohydrin benzoate $\mathbf{6 5} \mathrm{g}$ is in fact masked aldehyde 66 which could be made to ring-close onto the proline nitrogen after deprotection of the latter to give optically pure indolizidine type structures.

The synthesis of compounds $\mathbf{5 7}$ and $\mathbf{5 8}$ in Scheme 11 above is but one example of a much more general strategy towards fluorinated $\alpha$-amino acids, a class of compounds that is rapidly gaining in importance. ${ }^{[35]}$ In addition to acting as building blocks to

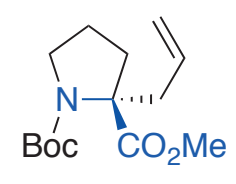

63

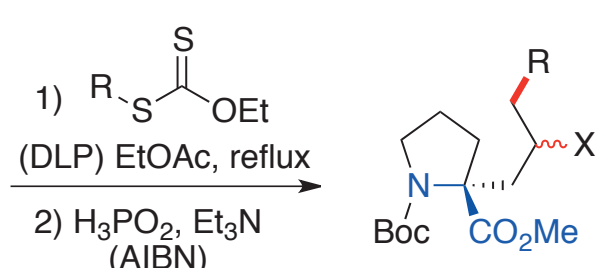

(AIBN)

dioxane, reflux $64, X=-S C(=S) O E t$

$65, X=H$

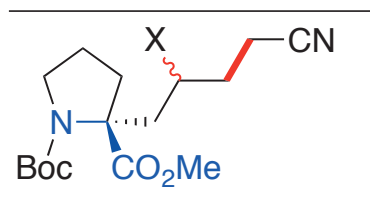

64a, $84 \%$; 65a, 78\%<smiles>[X]C(CCC(=O)N(C)OC)CC1CCCN1C(=O)OCc1ccccc1</smiles>

64c, $80 \%$; 65 c, $73 \%$<smiles>[X]C(CCC(=O)C(OC)OC)C[C@@]1(COC)CCCN1C(=O)O</smiles>

64 e, $77 \%$; $65 e, 76 \%$

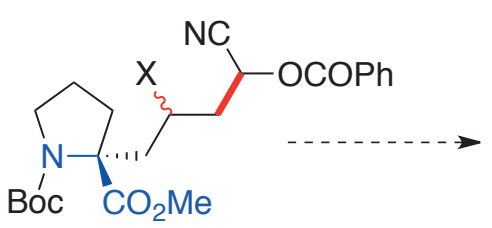

64g, 76\%; 65g, 72\%<smiles>[X]C(CCC(OC)OC)CC1CCCN1C(=O)OCc1ccccc1</smiles>

$64 b, 80 \% ; 65 b, 81 \%$<smiles>[X]C(CCC(=O)c1ccc(Br)cc1)CC1(COC(=O)O)CCCN1C(=O)OCc1ccccc1</smiles>

64d, $88 \%$; 65d, $75 \%$<smiles>[X]C(CC[NH+]c1ccccc1)C[C@@]1(C(=O)OC)CCCN1C(=O)O</smiles>

64f, $78 \%$; $65 f$, $79 \%$<smiles>COC(=O)[C@]1(CCCC=O)CCCN1C(=O)OCc1ccccc1</smiles>

66 
construct structures with improved chemical, biological, and biophysical properties, fluorinated $\alpha$-amino acids have proved highly valuable as reporter motifs in the ${ }^{19} \mathrm{~F}$ NMR spectroscopic analysis of peptides and proteins. ${ }^{[36]}$ Xanthate $\mathbf{6 7}$ allows the straightforward introduction of a trifluoromethyl group and its addition to vinyl glycine derivative 52 furnishes adduct 68 (Scheme 14). The use of the ponderous octadecyl appendage is mainly to avoid handling a volatile fluorinated xanthate. ${ }^{[37]}$ Reductive dexanthylation furnishes compound 69, a protected form of 5,5,5-trifluoronorvaline 70. Both 5,5,5-trifluoronorvaline 70 and 6,6,6-trifluoronorleucine 71 are useful as modifiers of biologically active peptides. ${ }^{[38]}$ They are commercially available but very expensive substances (200$400 \mathrm{USD} / \mathrm{g}$ ) because of the complexity of their synthesis. ${ }^{[39]}$ In the same manner, trifluoromethylated proline derivatives $\mathbf{7 3}$ and 75 were prepared by addition of reagent 67 to alkenes 59 and 63 , respectively. The reductive removal of the xanthate in adduct $\mathbf{7 2}$ was advantageously accomplished with DLP in isopropanol. The Barton procedure in this case gave a product contaminated with octadecanol.

Placing the trifluoromethyl group on the alkene partner is an alternative convenient route to fluorinated $\alpha$-amino acids. This variant is illustrated by the addition of various xanthates to allylmorpholinone 76, a compound readily prepared according to the procedure of Brigaud from commercial D-2-phenylglycine. ${ }^{[40]}$ Radical additions to this alkene lead to protected $(S)-\alpha-\mathrm{Tfm}-$ amino acids $(\mathrm{Tfm}=$ trifluoromethyl) 78a-e after removal of the xanthate group from the corresponding initial adducts $77 \mathbf{a}-\mathbf{e}$ (Scheme 15). The last example, 78e, is particularly interesting as it is in fact masked $(S)$ - $\alpha$-Tfm-lysine 79, an apparently unknown fluorinated amino acid, at least in the open literature. The lower congener, $\alpha$-Tfm-ornithine $\mathbf{8 0}$, has been prepared from<smiles>NC(CC1CCC1(F)F)C(=O)O</smiles>

70, $\mathrm{n}=1 ; 5,5,5$-trifluoronorvaline 71, $\mathrm{n}=2 ;$ 6,6,6-trifluoronorleucine<smiles>COC(=O)NC(CCC(F)(F)F)C(=O)OC</smiles>

$69,76 \%$

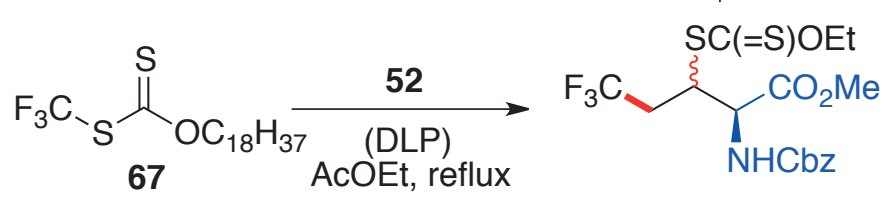

67

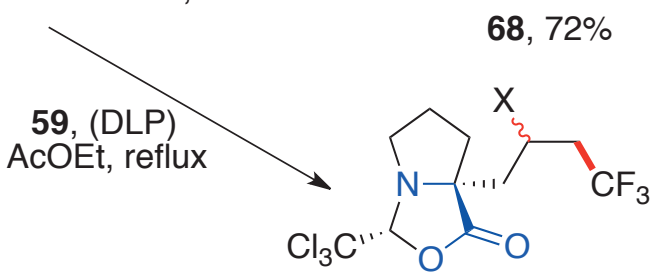

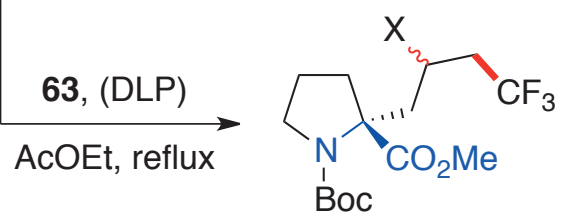

$\mathrm{H}_{3} \mathrm{PO}_{2}$, TEA, ( $74, \mathrm{X}=\mathrm{X}=-\mathrm{SC}(=\mathrm{S}) \mathrm{OEt}, 71 \%$

(AIBN), dioxane reflux

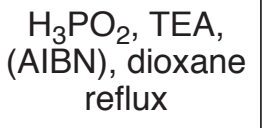

racemic carboxamide $\mathbf{8 1}$ by a Hoffmann-type degradation. ${ }^{[41]}$ It is worth noting that racemic difluoromethyl-ornithine $\mathbf{8 2}$ (eflornithine) is clinically employed for the treatment of sleeping sickness. ${ }^{[42]}$

The last example in this series concerns the reaction of $S$-trifluoromethyl xanthate $\mathbf{8 3}$ with the same allylmorpholinone 76 depicted in Scheme 16. Both the xanthate and the alkene partners bear a trifluoromethyl group. Dexanthylation of the corresponding adduct $\mathbf{8 4}$ gives rise to product $\mathbf{8 5}$, a masked form of 6,6,6-trifluoro- $\alpha$-Tfm-norleucine $\mathbf{8 6}$ and, so far, an unknown $\alpha$-trifluoromethyl analog of 6,6,6-trifluoro-norleucine described by Ojima in 1989. [39c]

\section{Perspectives}

The ability of xanthates and related congeners to mediate the creation of carbon-carbon bonds on electronically unbiased alkenes in both inter and intramolecular fashion opens vast possibilities for the synthesis of amino acids. This overview has concentrated on $\alpha, \beta$, and $\gamma$-amino acids because of their relevance to medicinal chemistry, but amino acids in general have numerous other applications, especially for the manufacture of polyamide polymers. Since the distance between the amino and carboxylic acid moieties can be made as long or as short
76

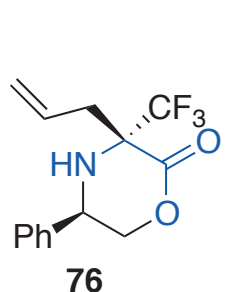

(M)

77 a, $72 \% ; 78 a, 76 \%$<smiles>[X]C(CCC(=O)c1ccc(Br)cc1)C[C@]1(C(F)(F)F)N[C@@H](c2ccccc2)COC1=O</smiles><smiles>[X]C(CCC(=O)C(OC)OC)C[C@]1(C(F)(F)F)N[C@@H](c2ccccc2)COC1=O</smiles>

77b, 66\%; 78b, 72\%<smiles>[X]C(CCC#N)C[C@]1(C(F)(F)F)N[C@@H](c2ccccc2)COC1=O</smiles>

77d, 70\%; 78d, 76\% 77c, $73 \% ; 78 c, 67 \%$
$\mathrm{Et}_{3} \mathrm{~N}$

(AIBN)

77, $\mathrm{X}=-\mathrm{SC}(=\mathrm{S}) \mathrm{OEt}$

78, $\mathrm{X}=\mathrm{H}$<smiles>[Y]C(CCNc1ccccc1)C[C@]1(C(F)(F)F)N[C@H](c2ccccc2)COC1=O</smiles>

79 ( $\alpha$-trifluoromethyl lysine)<smiles>NCCCC(NC(=O)OCc1ccccc1)(C(=O)O)C(F)(F)F</smiles><smiles>NC(=O)CCCC(N)(C(=O)O)C(F)(F)F</smiles><smiles>NCCCC(N)(C(=O)O)C(F)(F)F</smiles>

82 (eflornithine) 
<smiles>C=CCC1(C(F)(F)F)N[C@@H](c2ccccc2)COC1=O</smiles>

Scheme 16. Synthesis of a protected bis(trifluoromethyl) substituted amino acid.

as desired by a suitable choice of the reactants, the synthesis of a large variety of amino acid monomers becomes almost trivial. This is highlighted by the addition of xanthate 87 to methyl 10-undecenoate to give amino ester $\mathbf{8 8}$ (Scheme 17). ${ }^{[43]}$ Interestingly, methyl 10-undecenoate is derived from castor oil, and this represents a practical approach for the valorisation of the biomass.

No work has yet been done on $\alpha$-aminophosphonic acids, another class of medicinally useful compounds, ${ }^{[44]}$ but, as depicted in Scheme 17, the addition of xanthate $\mathbf{8 7}$ to diethyl allylphosphonate proceeds smoothly to give $\delta$-aminophosphonate 89. ${ }^{[43]}$ Another amusing example is the addition of malonyl xanthate $\mathbf{9 0}$ to commercially available $N$-vinyl phthalimide to give adduct $\mathbf{9 1}$, which in turn can be added to dimethyl alkylphosphonate to afford product 92, after reductive removal of the xanthate group. This compound is at the same time a masked $\gamma$-amino acid and a $\delta$-aminophosphonic acid. To access $\alpha$-aminophosphonic acids, the required $\alpha$-aminophosphonic motif could in principle be placed on the alkene, the xanthate, or both.

$\beta$-Lactams are masked $\beta$-amino acids that can also be accessed by this chemistry. One example is displayed in the lower part of Scheme 17, where $\beta$-lactam xanthate 93 is added to Feist's ester 94 to give adduct 95. ${ }^{[45]} \beta$-Lactams constitute a hugely important family ${ }^{[46]}$ and the present route provides many structures not readily available otherwise.

Many aspects in this area remain to be explored. Xanthates bearing chiral $\alpha-, \beta$-, or $\gamma$-amino acid motifs allowing direct access to optically pure amino acids are still needed. One solution is by asymmetric reductive amination of $\alpha$-ketoesters and asymmetric reduction of $\alpha$-oximinoesters. These are well-known routes to chiral non-racemic $\alpha$-amino acids. ${ }^{[3]}$ Preliminary studies have indicated that $\alpha$-ketoesters and $\alpha$-oximinoesters can be obtained by the usual xanthate addition, one example being the addition of xanthate 96 to allyl acetate (Scheme 18). The resulting addition product 97 could in principle be processed into amino acid 98. ${ }^{[47]}$

Finally, little use was made of the xanthate group in the adducts; it was simply reductively removed. Hydrolytic cleavage, for example by aminolysis, would give rise to the corresponding thiols. In most of the examples described in the present overview, the corresponding mercapto amino acids obtained after deprotection would constitute ideal substrates for the native chemical ligation. Native chemical ligation is an ingenious

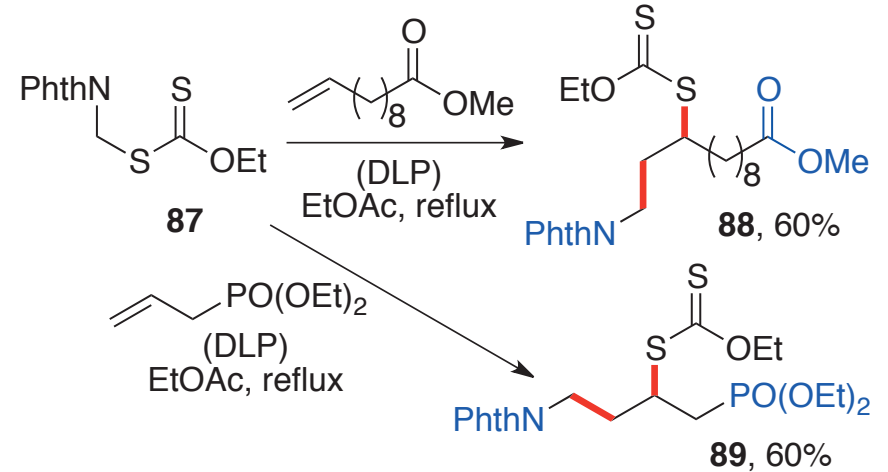

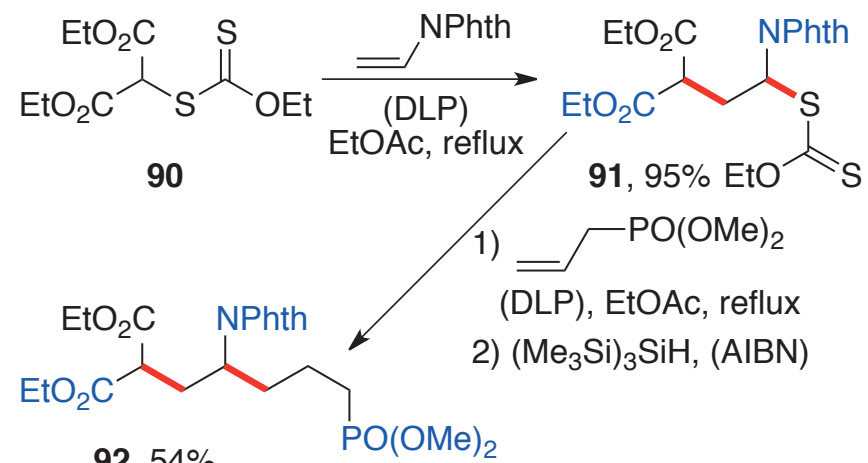

92, $54 \%$

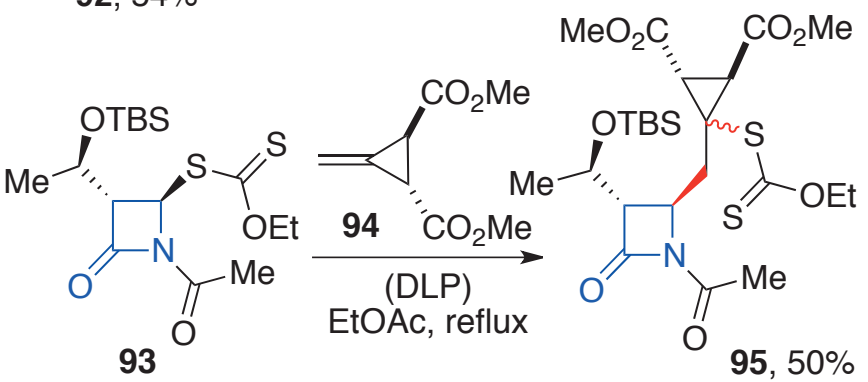

Scheme 17. Synthesis of protected aminophosphonic acids and $\beta$-lactams.

technique based on thiolesters derived from 2- and 3-mercapto amino acids that allows the formation in an aqueous medium of a peptide bond between two polypeptide fragments. ${ }^{[48]}$ However, only cysteine and mercaptovaline are commercially available; other 2- and 3-mercapto amino acids have to be prepared as needed. For instance, the synthesis of protected 3-mercaptolysine 100 required 12 linear steps from protected aspartic acid 99. [49] Compound 102, the synthetic equivalent of protected 3-mercaptolysine derivative 100, should be accessible in only one step by addition of xanthate $\mathbf{8 7}$ to protected enantiomerically pure allyl glycine 102. 3-Mercaptolysine derivative $\mathbf{1 0 1}$ would arise from both compounds $\mathbf{1 0 0}$ and $\mathbf{1 0 2}$ by cleavage of the thioacetate or the xanthate group, respectively. Notice that cleavage to the xanthate in adduct $\mathbf{5 3 \mathbf { j }}$ would lead to a protected 2-mercaptoornithine.

\section{Acknowledgements}

This article is affectionately dedicated to Professor Wolf-D. Woggon (University of Basel). I should like to thank my co-workers, whose names appear in the references, for their skill and dedication. I have a special debt to Dr Béatrice Sire, who has made major contributions to our projects over 25 years and who has now retired. I also thank the following companies and organizations that have provided financial support over the years: Ecole Polytechnique, CNRS, DGA, MNRT, the Alfred Kastler Foundation, the China Research Council, and Rhodia (now Solvay). 

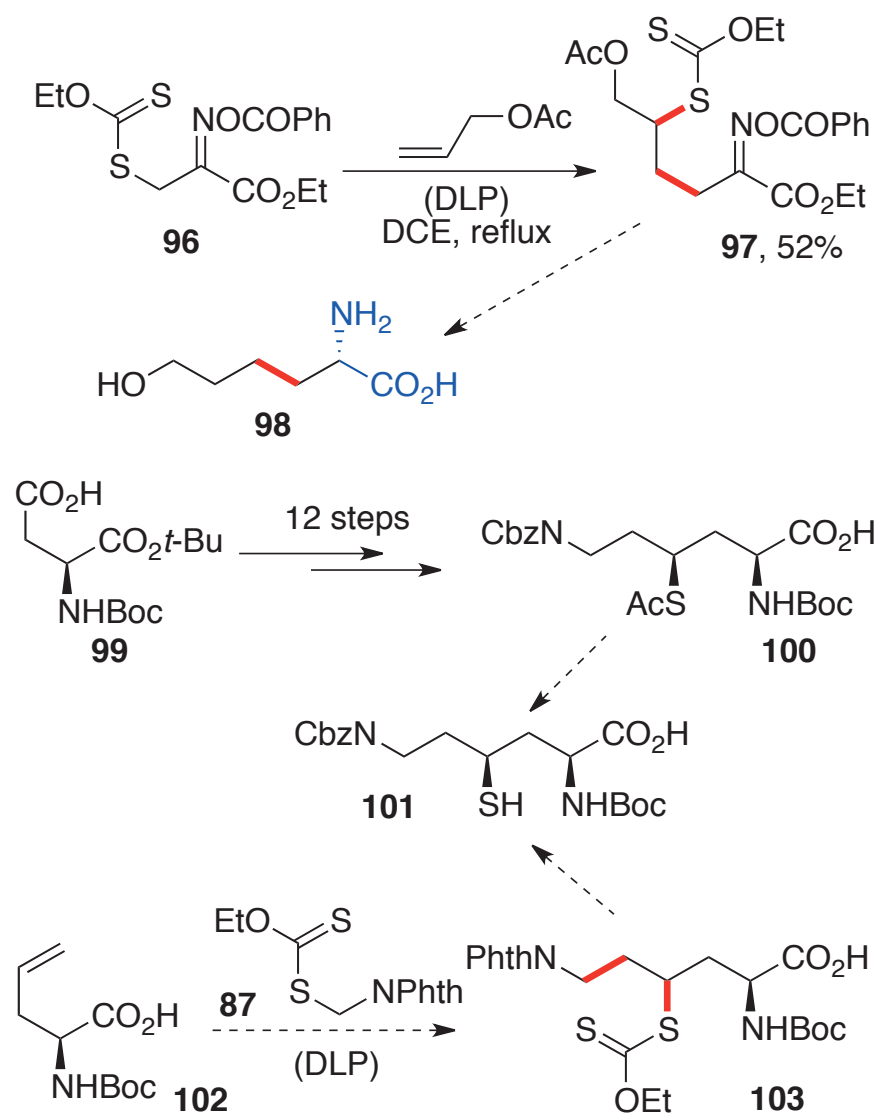

Scheme 18. Other routes to amino acids and to mercapto amino acids.

[1] a) 'Amino Acids, Peptides and Proteins in Organic Chemistry', Ed. A. B. Hughes, Wiley-VCH, Weinheim, 2009, Vol. 1\&2; b) G. C. Barrett, D T. Elmore, 'Amino Acids and Peptides', Cambridge University Press, Cambridge, 2004

[2] a) 'Enantioselective Synthesis of $\beta$-Amino Acids', Ed. E. Juaristi, Wiley, New York, 1997; b) M. Liu, M. P. Sibi, Tetrahedron 2002, 58, 7991; c) 'Enantioselective Synthesis of $\beta$-Amino Acids', Eds. E. Juaristi, V. Soloshonok, Wiley, Hoboken, NJ, 2005; d) L. Kiss, F. Fülöp, Chem. Rev. 2014, 114, 1116; (e) F. Fülöp, T.A. Martinek, G. K. Tóth, Chem. Soc. Rev. 2006, 35, 323; f) R. B. Silverman, Chem. Rev. 2018, 118, 4037; g) J. Caruano, G. G. Mucciolib, R. Robiette, Org. Biomol. Chem. 2016, 14 , 10134; h) C. Lamberth, Tetrahedron 2010, 66, 7239

[3] M. Blaskovich, 'Handbook on Syntheses of Amino Acids: General Routes for the Syntheses of Amino Acids', Oxford University Press, New York, 2010.

[4] a) B. Quiclet-Sire, S. Z. Zard, Top. Cur. Chem. 2006, 264, 201; b) B. QuicletSire, S. Z. Zard, Chem. Eur. J. 2006, 12, 6002; c) B. Quiclet-Sire, S. Z. Zard, Pure Appl. Chem. 2011, 83, 519.

[5] a) S. Z. Zard, J. Phys. Org. Chem. 2012, 25, 953-964; b) S. Z. Zard, Helv. Chim. Acta 2019, 102, e1900134.

[6] M. D. Bachi, A. De Mesmaeker, N. Stevenart-De Mesmaeker, Tetrahedron Lett. 1987, 28, 2637.

[7] L. Boiteau, J. Boivin, B. Quiclet-Sire, J.-B. Saunier, S. Z. Zard, Tetrahedron 1998, 54, 2087.

[8] a) J. H. Udding, J. P. M. Giesselink, H. Hiemstra, W. N. Speckamp, Bull. Soc. Chim. Belg. 1994, 103, 329; b) J. H. Udding, H. Hiemstra, W. N. Speckamp, J. Org. Chem. 1994, 59, 3721.

[9] a) P. Delduc, C. Tailhan, S. Z. Zard, J. Chem. Soc., Chem. Commun. 1988, 308; b) F. Mestre, C. Tailhan, S. Z. Zard, Heterocycles 1989, 28, 171

[10] B. Quiclet-Sire, Y. Yanagisawa, S. Z. Zard, Chem. Commun. 2014, 50, 2324.

[11] M.-G. Braun, B. Quiclet-Sire, S. Z. Zard, J. Am. Chem. Soc. 2011, 133, 15954.

[12] L. Debien, B. Quiclet-Sire, S. Z. Zard, Acc. Chem. Res. 2015, 48, 1237.

[13] B. Quiclet-Sire, B. Sortais, S. Z. Zard, Chem. Commun. 2002, 1692.

[14] P. Blakskjaer, L. Pedersen, T. Skrydstrup, J. Chem. Soc., Perkin Trans. 1 2001, 910 .

[15] A. Liard, B. Quiclet-Sire, S. Z. Zard, Tetrahedron Lett. 1996, 37, 5877.

[16] B. Quiclet-Sire, S. Seguin, S. Z. Zard, Angew. Chem. Int. Ed. Engl. 1998, 37, 2864.

[17] a) T. Hintermann, D. Seebach, Synlett 1997, 437; b) D. Seebach, K. Gademann, J. V. Schreiber, J. L. Matthews, T. Hintermann, B. Jaun, L. Oberer, U. Hommel, H. Widmer, Helv. Chim. Acta 1997, 80, 2033.
[18] S. Han, R. A. Jones, B. Quiclet-Sire, S. Z. Zard, Tetrahedron 2014, 70, 7192.

[19] a) D. H. R. Barton, D. O. Jang, J. Cs. Jaszberenyi, Tetrahedron Lett. 1992, 33, 5709; b) J. Boivin, R. Jrad, S. Juge, V. T. Nguyen, Org. Lett. 2003, 5, 1645.

[20] B. Quiclet-Sire, S. Z. Zard, Synlett 2016, 27, 680.

[21] P. A. Frey, Acc. Chem. Res. 2014, 47, 540.

[22] P. Spiteller, F. von Nussbaum, ' $\beta$-Amino Acids in Natural Products' in 'Enantioselective Synthesis of $\beta$-Amino Acids', Eds. E. Juaristi, V. Soloshonok, Wiley, Hoboken, NJ, 2005, pp 19-91.

[23] X. Chen, S. Z. Zard, unpublished observation.

[24] B. Quiclet-Sire, G. Revol, S. Z. Zard, Org. Lett. 2009, 11, 3554.

[25] M. Heinrich, S. Z. Zard, Org. Lett. 2004, 6, 4969.

[26] M. Newcomb, 'Radical Kinetics and Clocks', in 'Encyclopedia of Radicals in Chemistry, Biology and Materials', Eds, C. Chatgilialoglu, A. Studer, John Wiley \& Sons, 2012, pp107-124.

[27] a) C. Chatgilialoglu, D. Crich, M. Komatsu, I. Ryu, Chem. Rev. 1999, 99, 1991; b) A. Banerjee, Z. Lei, M.-Y. Ngai, Synthesis 2019, 51, 303.

[28] C. Nájera, J. M. Sansano, Chem. Rev. 2007, 107, 4584

[29] a) G. Dardenne, J. Casimir, M. Marlier, P. O. Larsen, Phytochemistry 1974, 13, 1897; b) R. R. Rando, Biochemistry 1974, 13, 3859; c) R. R. Rando, N. Relyea, L. Cheng, J. Biol. Chem. 1976, 251, 3306.

[30] S. Li, F. Portela-Cubillo, S. Z. Zard, Org. Lett. 2016, 18, 1888

[31] M.-P. Denieul, B. Quiclet-Sire, S. Z. Zard, J. Chem. Soc., Chem. Commun. 1996, 2511

[32] C. B. Kelley, M. A. Mercadante, N. E. Leadbeater, Chem. Soc. Rev. 2013, 49, 11133 .

[33] N. Sewald, H.-D. Jakubke, 'Peptides: Chemistry and Biology', Wiley-VCH, Weinheim, 2002.

[34] G. D. Artman, R. J. Rafferty, R. M. Williams, Org. Synth. 2009, 86, 262.

[35] a) 'Fluorine Containing Amino Acids - Synthesis and Properties', Eds. V. P. Kukhar, V. A. Soloshonok, Wiley, Chichester, 1995; b) J. Moschner, V. Stulberg, R. Fernandes, S. Huhmann, J. Leppkes, B. Koksch, Chem. Rev. 2019, 119, 10718

[36] a) M. Salwiczek, E. K. Nyakatura, U. I. M. Gerling, S. Ye, B. Koksch, Chem. Soc. Rev. 2012, 41, 2135; b) E. N. G. Marsh, Acc. Chem. Res. 2014, 47, 2878.

[37] Bertrand, F.; Pevere, V.; Quiclet-Sire, B.; Zard, S. Z. Org. Lett. 2001, 3, 1069.

[38] H. Meng, C. A. Clark, K. Kumar, in 'Fluorine in Medicinal Chemistry and Chemical Biology', Ed. I. Ojima, Wiley-Blackwell, Chichester, 2009, p 411.

[39] a) H. M. Walborsky, M. Baum, D. F. Loncrint, J. Am. Chem. Soc. 1955, 77, 3637; b) I. Ojima, M. Okabe, K. Kato, H. B. Kwon, I. T. Horvath, J. Am. Chem. Soc. 1988, 110, 150; c) I. Ojima, K. Kato, K. Nakahashi, J. Org. Chem. 1989, 54, 4511.

[40] Chaume, G.; Van Severen, M. C.; Marinkovic, S.; Brigaud, T. Org. Lett. 2006, 8, 6123 .

[41] a) A. Dal Pozzo, L. Muzi, M. Moroni, R. Rondanin, R. De Castigilione, P. Bravo, M. Zanda, Tetrahedron 1998, 54, 6019;(b) M. Moroni, B. Koksch, S. N. Osipov, M. Crucianelli, M. Frigerio, P. Bravo, K. Burger, J. Org. Chem. 2001, 66, 130.

[42] a) A. S. Nagle, S. Khare, A. B. Kumar, F. Supek, A. Buchynskyy, C. J. N. Mathison, N. K. Chennamaneni, N. Pendem, F. S. Buckner, M. H. Gelb, V. Molteni, Chem. Rev. 2014, 114, 11305; for an update on the available drugs for the chemotherapy of human African trypanosomiasis, see: b) P. P. Simarro, J. Franco, A. Diarra, J. A. Ruiz Postigo, J. Jannin, Parasitology 2012, 139, 842 .

[43] B. Quiclet-Sire, S. Z. Zard, Org. Lett. 2008, 10, 3279

[44] a) A. Mucha, P. Kafarski, Y. Berlicki, J. Med. Chem. 2011, 54, 5955; b) M. Ordóñez, J. L. Viveros-Ceballos, C. Cativiela, F. J. Sayago, Tetrahedron, $\mathbf{2 0 1 5}, 71,1745$

[45] B. Quiclet-Sire, S. Z. Zard, Heterocycles 2010, 82, 263.

[46] 'Beta-lactams', Ed. B. K. Banik, Springer, 2017.

[47] F. Gagosz, S. Z. Zard, unpublished observations.

$48]$ a) V. T. Pattabiraman, J. W. Bode, Nature, 2011, 480, 471; b) L. Raibaut, N. Ollivier, O. Melnyk, Chem. Soc. Rev. 2012, 41, 7001; c) H. P. Hemantha, N. Narendra, V. V. Sureshbabu, Tetrahedron 2012, 68, 9491.

[49] a) R. Yang, K. K. Pasunooti, F. Li, X. W. Liu, C. F. Liu, J. Am. Chem. Soc. 2009, 131, 13592; b) J. Marin, C. Didierjean, A. Aubry, J. R. Casimir, J. P. Briand, G. Guichard, J. Org. Chem. 2004, 69, 130.

\section{License and Terms}

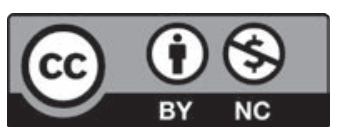

This is an Open Access article under the terms of the Creative Commons Attribution License CC BY_NC 4.0. The material may not be used for commercial purposes.

The license is subject to the CHIMIA terms and conditions: (http:// chimia.ch/component/sppagebuilder/?view=page $\& i d=12$ ).

The definitive version of this article is the electronic one that can be found at doi:10.2533/chimia.2020.9 